Jahangirnagar University J. Biol. Sci. 9(1 \& 2): 49-58, 2020 (June \& December)

\title{
Estimation of accumulated degree hours-based post-mortem intervals in mammalian and avian model
}

\author{
Md. Golam Mostafa ${ }^{*}$, Mst. Shahanaz Parvin Shobha, Anjuman Ara and \\ Saadia Ahmad \\ Department of Zoology, Jahangirnagar University, Savar, Dhaka-1342, Bangladesh
}

\begin{abstract}
The post-mortem interval (PMI) of a jungle cat (Felis chaus) and a chicken (Gallus gallus domesticus) were estimated as a mammalian and an avian model, respectively. The estimations were performed adopting the Accumulated Degree Hours (ADH) method using blowfly, Lucilia sericata. The required developmental time from oviposition to the $3^{\text {rd }}$ instar larvae of the blowfly species was considered for the determination of PMI in each of the study. The results revealed that the calculated PMI of jungle cat was 5.29 days. On the other hand, the estimated PMI of the chicken was 2.83 days. The difference of these two PMIs in two different models might be due to the variation of temperatures and other related factors in the development of the larvae of the blowfly species. This study might offer a new approach in the medico-legal investigations with a view to resolving homicide as well as other suspected death of animals including wildlife in Bangladesh.
\end{abstract}

Key words: Estimation, PMI, Mammalian, Avian, ADH method.

\section{INTRODUCTION}

Forensic entomology is a field of forensic sciences, which deals with insect-based information in the investigation of legal cases relating to unnatural deaths of humans or other animals including wildlife (Gennard, 2007). The most important application of forensic entomology is the estimation of Post-mortem interval (PMI), which means the time that has elapsed since the death of the victim. PMI possesses great potentials in the medico-legal investigations of homicides and other unnatural deaths of animals (Byrd \& Castner, 2000). Since many insects are associated with the dead bodies, they are always a potential source of evidence in case of human murders and suspicious deaths of animals including poaching or illegal hunting of wildlife.

After the death of an animal, insects are usually the first organisms to appear on the dead body to colonize in a successive way (Catts \& Goff, 1992). The cadaver undergoes a recognized sequence of decompositional stages from fresh to skeletal over time and inherently follows remarkable physical, biological as well as different chemical changes (Byrd \& Castner, 2009). During the course of decomposition, different types of

\footnotetext{
*Corresponding author. Email: bdmostafa@yahoo.com
} 
arthropods predominantly insects complete their life cycles on the dead body (Byrd \& Castner, 2000).

The insect-based information can help in the precise estimation of PMIs in animals including humans. The immature stages of the insects particularly the sarcophagous insects found on the dead body can provide evidence in estimating the PMI ranging from one day up to a month or more depending on the insect species involved and the climatic conditions at the crime scene (Ahmed \& Joseph, 2016). Among the sarcophagous insects, the most commonly used insects in the forensic investigations are the true flies of order Diptera and the predominant families are Calliphoridae (blow flies), Sarcophagidae (flesh flies) and Muscidae (house flies). Among them Calliphorids and Sarcophagids generally arrive within minutes of the death of animals (Bala \& Sharma, 2016). However, without appropriate and professional approaches to the matter, particularly collection of insect evidence, presentation and accurate estimation of PMI, the judgments about the subject is affected in court (Amendt et al., 2011).

Many important homicide cases have been resolved in courts in the developed countries by using entomological data with effective and well-established techniques. Among them such cases in France, Belgium, England, Czech Republic, Russia, Canada and in the United States are exemplary (Benecke, 1998).

Khatun et al., (2019) carried out first experiment on the estimation of PMI in Bangladesh, but still the field remains unexplored and obscure in this country largely because of lack of awareness of the benefits. Although the experiment on the estimation of PMI in human models is utterly important, the present study was carried out using a jungle cat and chicken model because human dead bodies cannot be easily used due to legal complications.

\section{MATERIALS AND METHODS}

The study was conducted from February to April in 2019 in the Botanical Garden and at the Medical and Forensic Entomology laboratory of Department of Zoology in Jahangirnagar University. In this study netted forensic cage, insect rearing cages, glass vials, forceps, thermometer, hygrometer, incubator, alcohol, plastic cups, sweeping net, scales, needles, slides, dissecting and light microscopes, formalin, masks, gloves and polythene bags were used as to perform the experiments.

The experiment and the experimental animals were a dead jungle cat (Felis chaus) and a chicken (Gallus gallus domesticus). The dead body of the jungle cat was found near the Wazed Miah Science Research Center in Jahangirnagar University campus while the carcass of the chicken was collected from the dumping ground near the Jahangirnagar University campus area.

Blow fly larvae were collected from the cadaver and reared in the laboratory on rotten Tilapia fish as their natural diet. The development time of $L$. sericata (Meigen) from egg to pupae were observed at temperature of $21.3 \pm 1{ }^{\circ} \mathrm{C}$ and $31 \pm 1{ }^{\circ} \mathrm{C}$ respectively because of 
the prevailing average temperature of that particular time of the study sites and the rearing was completed to obtain their adult stages for morphological identification of the insects. The adult insect samples were collected from the corpse and preserved in $80 \%$ ethanol for identification.

Maximum and minimum temperature data of the experimental period were recorded from Geography and Environment department of Jahangirnagar University. The developmental stages of blow fly and the instars were determined by their size and the number of slits present in the posterior spiracles (Youseffi et al., 2012). The identification of the adult fly was done by studying their morphological characters under light microscope as described by Williams et al., (2014). The ADH method was used to determine the PMIs in both model animals as described by Khatun et al., (2019) and Suri Babu et al., (2013). The $\mathrm{ADH}$ was calculated for $L$. sericata life cycle in both cases by using the following formula: ADH=Time (Hrs.) $\times$ (Average temperature-Minimum development threshold temperature) and the reference developmental durations for L. sericata used in the study were obtained from Cervantes et al., (2017).

\section{RESULTS AND DISCUSSION}

Identification of adults and larvae: The adult flies were metallic green in color with a (Plate 1) ridge just above the squama. The rear wing was flap-like with tufts of hair on it and a yellow bicosta. There were four para-vertical setulae or occipital bristles and metallic blue to black fore femora. The life cycle of this blow fly included eggs, three larval instars, pupa and adults. The eggs were found usually ball like, white or pale yellow. The larvae were yellow or grayish in color and conical in shape and passed three instars (Plate 2). The $1^{\text {st }}$ instar larvae were identified by one slit, $2^{\text {nd }}$ instar larvae were identified by two slits and $3^{\text {rd }}$ instar larvae were identified by three slits in the posterior spiracles (Plates 3 and 4).

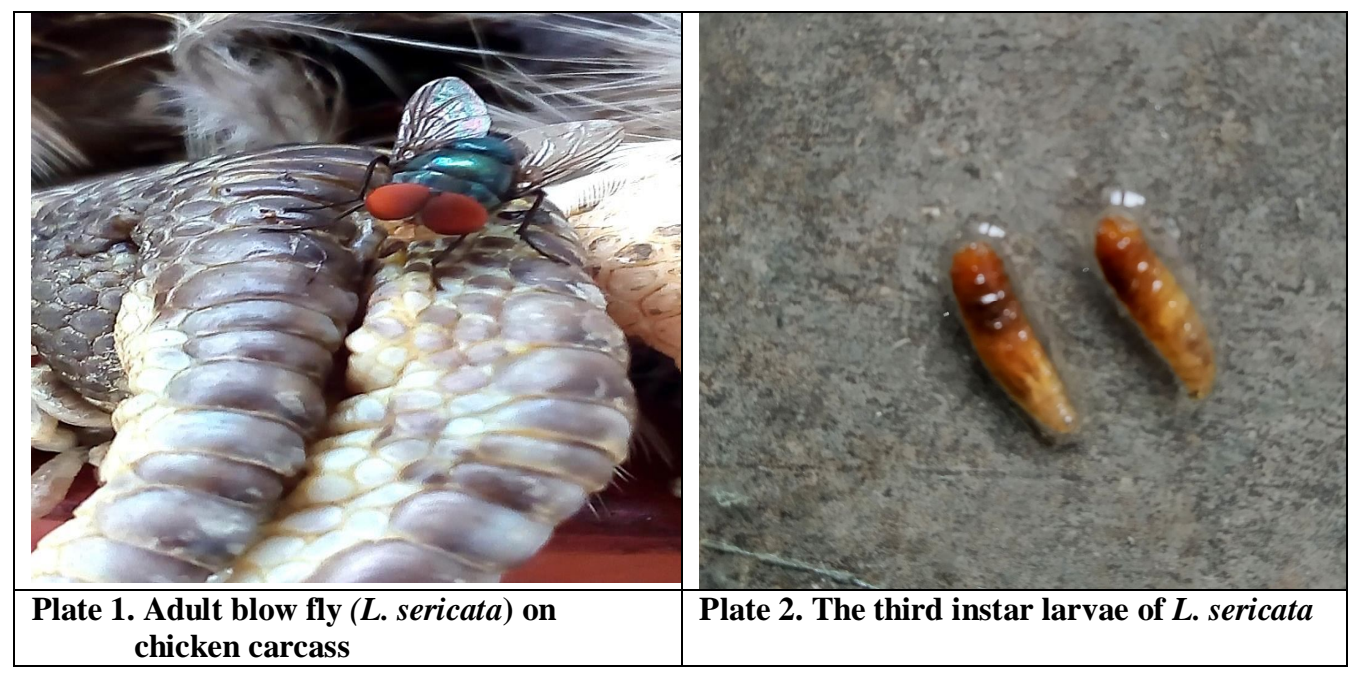




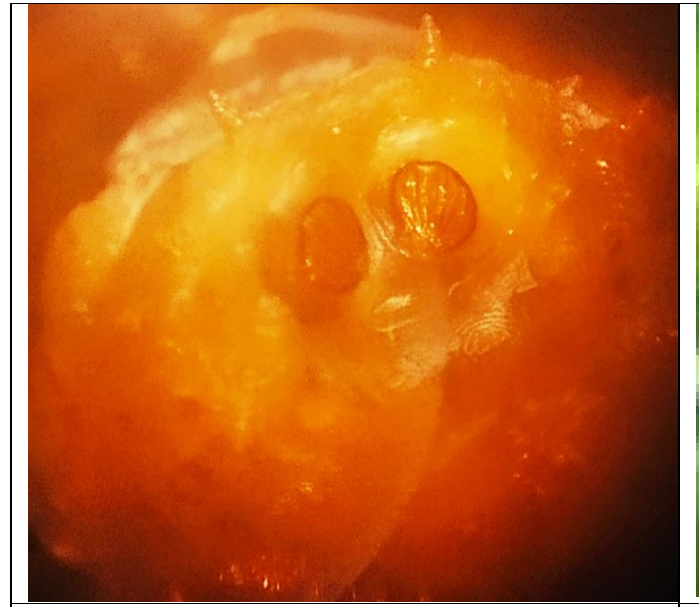

Plate 3. Posterior spiracles of the 3rd instar larvae of L. sericata

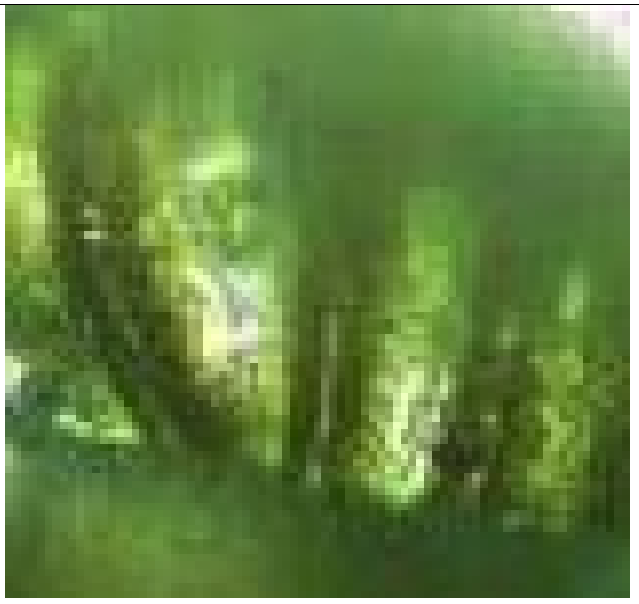

Plate 4. Three slits in the posterior spiracles of the 3rd instar larvae of $L$. sericata

Estimation of PMI: By observing different developmental stages of L. sericata and different decompositional stages of the dead bodies the PMI of a chicken (Plate 1) and of a jungle cat (Plate 5 and 6) and were estimated. The temperature of the study area was $21.3 \pm 1^{\circ} \mathrm{C}$. The development time of $L$. sericata at $24^{\circ} \mathrm{C}$ was utilized to calculate ADH. Cumulative $\mathrm{ADH}$ required for the development of the $3^{\text {rd }}$ instar larvae of the fly was calculated by using meteriological data of the study site as shown in Table 1. Finally, the time of death and PMI of the mammalian (Table 2) and avian model were estimated by using the ADH method (Table 3 and Table 4).

Estimation of PMI of the jungle cat

Table 1. Accumulated Degree Hours (ADH) for $L$. sericata from $1^{\text {st }}$ February to 9 th February 2019

\begin{tabular}{|c|c|c|c|c|c|c|c|}
\hline \multirow[t]{2}{*}{ Date } & \multicolumn{3}{|c|}{ Temperature ${ }^{\circ} \mathrm{C}$} & \multirow{2}{*}{$\begin{array}{l}\text { Threshold } \\
\text { Temp. }{ }^{\circ} \mathrm{C}\end{array}$} & \multirow{2}{*}{$\begin{array}{l}\text { Degree } \\
\text { Day } \\
\text { (DD) }\end{array}$} & \multirow{2}{*}{$\begin{array}{l}\text { Accumulated } \\
\text { Degree Hours } \\
(\mathrm{ADH})\end{array}$} & \multirow[t]{2}{*}{$\begin{array}{l}\text { Cumulative } \\
\text { ADH }\end{array}$} \\
\hline & Max. & Min. & Average & & & & \\
\hline $1 / 2 / 2019$ & 28.3 & 17 & 22.65 & 10 & 12.65 & 303.6 & 2318.6 \\
\hline $2 / 2 / 2019$ & 28.3 & 17.3 & 22.8 & 10 & 12.8 & 307.2 & 2015 \\
\hline $3 / 2 / 2019$ & 29.6 & 13.6 & 21.6 & 10 & 11.6 & 278.4 & 1707.8 \\
\hline $4 / 2 / 2019$ & 30.3 & 12.3 & 21.3 & 10 & 11.3 & 271.2 & 1429.4 \\
\hline $5 / 2 / 2019$ & 30.3 & 12.6 & 21.45 & 10 & 11.45 & 274.8 & 1158.2 \\
\hline $6 / 2 / 2019$ & 30 & 12 & 21 & 10 & 11 & 264 & 883.4 \\
\hline $7 / 2 / 2019$ & 29.6 & 11.3 & 20.45 & 10 & 10.45 & 250.8 & 619.4 \\
\hline $8 / 2 / 2019$ & 29.3 & 12 & 20.65 & 10 & 10.65 & 255.6 & 368.6 \\
\hline $9 / 2 / 2019$ & 29.6 & 13 & 21.3 & 10 & 11.3 & 113 & 113 \\
\hline
\end{tabular}

- The arrow sign indicates the position of required ADH in the table.

- $\quad$ Degree Days $(\mathrm{DD})=(\text { Average. Temp. }- \text { Threshold Temp. })^{\circ} \mathrm{C}$

- Accumulated Degree Hours $(\mathrm{ADH})=\mathrm{DD} \times \mathrm{x}$ Time in hours 
Table 2. Accumulated Degree Hours (ADH) method for determining the post -mortem interval (PMI) of a dead jungle cat

\begin{tabular}{|c|c|}
\hline \multicolumn{2}{|c|}{ Accumulated Degree Hours method } \\
\hline Collection of 3rd instar larvae & at 10.00 hours on $9^{\text {th }}$ February 2019 \\
\hline $\begin{array}{l}\text { The reference ADH taken by } L \text {. sericata to } \\
\text { reach the third instar stage at } 24^{\circ} \mathrm{C}\end{array}$ & $(15.8$ hrs. +42.3 hrs. $) \times 24^{\circ} \mathrm{C}=1394.4 \mathrm{ADH}$ \\
\hline Total ADH from $9^{\text {th }}$ to $5^{\text {th }}$ February (Table 1$)$ & $\begin{array}{l}\text { ADH }=\text { Development time }(\text { hrs. }) \times \text { Growing } \\
\text { Degree Day value }(\mathrm{DD})\left({ }^{\circ} \mathrm{C}\right) \\
\left(10 \text { hrs. } \times 11.3^{\circ} \mathrm{C}\right)+\left(24 \text { hrs. } \times 10.65^{\circ} \mathrm{C}\right)+(24 \\
\text { hrs. } \times \\
\left.10.45^{\circ} \mathrm{C}\right)+\left(24 \text { hrs. } \times 11^{\circ} \mathrm{C}\right)+(24 \text { hrs. } \times \\
\left.11.45^{\circ} \mathrm{C}\right) \\
=1158.2 \mathrm{ADH}\end{array}$ \\
\hline $\begin{array}{l}\text { Difference between ADH taken by L. sericata } \\
\text { species to reach the third instar stage at } 24^{\circ} \mathrm{C} \text { - } \\
\text { Total ADH of } 5^{\text {th }}, 6^{\text {th }}, 7^{\text {th }}, 8^{\text {th }}, 9^{\text {th }} \text { February } 2019\end{array}$ & $(1394.4-1158.2) \mathrm{ADH}=236.2 \mathrm{ADH}$ \\
\hline $\begin{array}{l}\text { Dividing } 236.2 \text { ADH by the Growing Degree } \\
\text { Day value(DD) of } 4^{\text {th }} \text { February } 2019(11.3) \\
\text { (Table } 1)\end{array}$ & $236.2 \mathrm{ADH} / 11.3^{\circ} \mathrm{C}=20.90 \mathrm{hrs}$. \\
\hline Determination of oviposition and PMI & $\begin{array}{l}\text { Backward counting of } 20.90 \text { hrs. from } \\
4^{\text {th }} \text { February } 2019 \text { revealed that the female } L . \\
\text { sericata species might have laid its eggs on } \\
\text { the dead body at } 3.10 \text { hrs.on } 4^{\text {th }} \text { February. } \\
\text { Total hours }=\left(9^{\text {th }} \text { February: } 10 \text { hrs. }+8^{\text {th }}\right. \\
\text { February: } 24 \text { hrs. }+7^{\text {th }} \text { February: } 24 \mathrm{hrs} .+6^{\text {th }} \\
\text { February: } 24 \mathrm{hrs} .+5^{\text {th }} \text { February: } 24 \mathrm{hrs} .+4^{\text {th }} \\
\text { February: } 20.90 \text { hrs. })=126.9 \mathrm{hrs}=5.29 \text { days }\end{array}$ \\
\hline $\begin{array}{l}\text { Thus the death of the jungle cat might occur a } \\
\text { PMI after obtaining the third instar larvae was }\end{array}$ & $\begin{array}{l}10 \text { hrs.on } 4^{\text {th }} \text { February } 2019 \text { and the calculated } \\
29 \text { days). }\end{array}$ \\
\hline
\end{tabular}

Dead body of jungle cat found

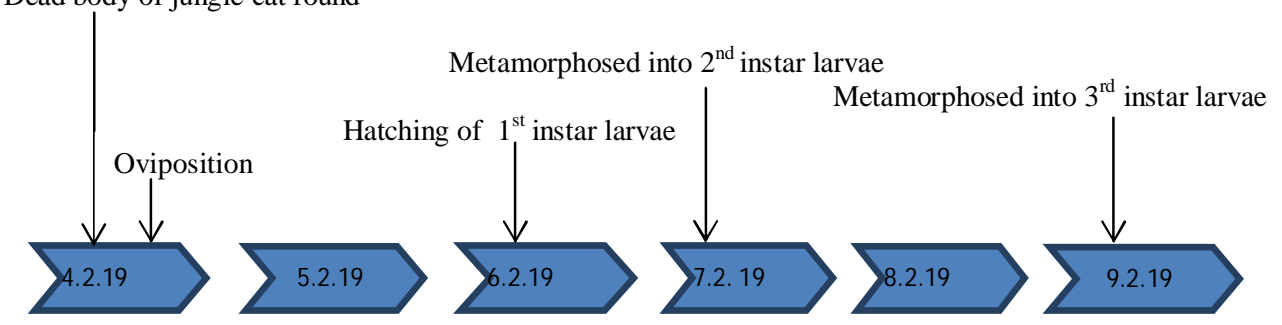

PMI based on $3^{\text {rd }}$ instar larvae of L. sericata

Fig. 1. The timeline indicating the main events in the dead body of the jungle cat 


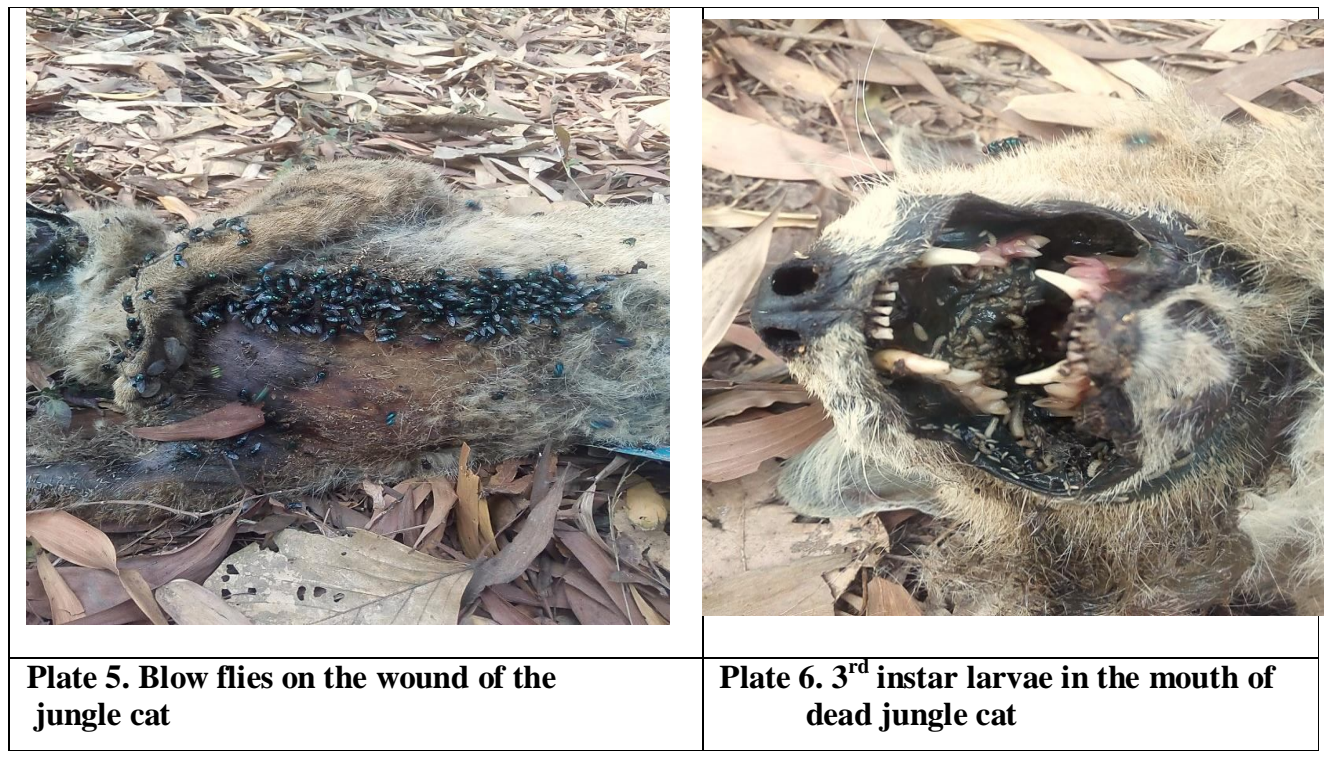

Estimation of PMI of the chicken

Table 3. Determination of Accumulated Degree Hours (ADH) for $L$. sericata from $29^{\text {th }}$ March to $2^{\text {nd }}$ April 2019

\begin{tabular}{c|c|c|c|c|c|l|c}
\hline \multirow{2}{*}{ Date } & \multicolumn{3}{|c|}{ Temperature in ${ }^{\circ} \mathrm{C}$} & \multirow{2}{*}{$\begin{array}{l}\text { Thresho } \\
\text { ld } \\
\text { Temp. } \\
{ }^{\circ} \mathrm{C}\end{array}$} & $\begin{array}{l}\text { Degree } \\
\text { Day (DD) }\end{array}$ & $\begin{array}{l}\text { Accumula } \\
\text { ted } \\
\text { Degree } \\
\text { Hours } \\
(\text { ADH) }\end{array}$ & $\begin{array}{l}\text { Cumulative } \\
\text { ADH }\end{array}$ \\
\cline { 2 - 6 } & Max. & Min. & Average & & 18.65 & 447.6 & 2031.9 \\
\hline $29 / 3 / 19$ & 32 & 25.3 & 28.65 & 10 & 18.3 & 439.2 & 1584.3 \\
$30 / 3 / 19$ & 31.6 & 25 & 28.3 & 10 & 18.3 & 1145.1 \\
$31 / 3 / 19$ & 29.3 & 22 & 25.65 & 10 & 15.65 & 375.6 & 769.5 \\
$1 / 4 / 19$ & 31.6 & 26.6 & 29.1 & 10 & 19.1 & 458.4 & 311.1 \\
$2 / 4 / 19$ & 31 & 25.6 & 28.3 & 10 & 18.3 & 311.1 & \\
\hline
\end{tabular}

- The arrow sign indicates the position of required ADH in the table.

- $\quad$ Degree Day $(\mathrm{DD})=(\text { Average } . \text { Temp. }- \text { Threshold Temp. })^{\circ} \mathrm{C}$

- Accumulated Degree Hours $(\mathrm{ADH})=\mathrm{DD} \times \mathrm{x}$ Time in hours 
Table 4. Accumulated Degree Hours (ADH) method for determining the Post-Mortem Interval (PMI) of a dead chicken

\begin{tabular}{ll}
\hline Accumulated Degree Hours method & \\
\hline Collection of $3^{\text {rd }}$ instar larvae & at 17.00 hours on $2^{\text {nd }}$ April 2019 \\
\hline $\begin{array}{l}\text { The reference ADH taken by } L \text {. sericata to reach } \\
\text { the third instar stage at } 30^{\circ} \mathrm{C} \text {. }\end{array}$ & $(11.2 \mathrm{hrs}+28.8 \mathrm{hrs}) \times 30^{\circ} \mathrm{C}=1200 \mathrm{ADH}$ \\
\hline Total ADH from $2^{\text {nd }}$ April to $31^{\text {th }}$ March & ADH= Development time $(\mathrm{hrs}) \times$ Growing \\
(Table 3) & Degree Day value (DD) $\left({ }^{\circ} \mathrm{C}\right)$ \\
& $\left(17 \mathrm{hrs} \times 18.3^{\circ} \mathrm{C}\right)+\left(24 \mathrm{hrs} \times 19.1^{\circ} \mathrm{C}\right)+(24 \mathrm{hrs}$ \\
& $\times$ \\
& $\left.15.65^{\circ} \mathrm{C}\right)=1145.1 \mathrm{ADH}$ \\
\hline
\end{tabular}

Difference between ADH taken by $L$. sericataspecies to reach the third instar stage at $(1200-1145.1) \mathrm{ADH}=54.9 \mathrm{ADH}$ $30^{\circ} \mathrm{C}$ - Total ADH of $1^{\text {st }}$ April, $2^{\text {nd }}$ April and $31^{\text {th }}$

March 2019

Dividing 54.9 ADH by the Growing Degree Day value(DD) of $30^{\text {th }}$ March 2019 (18.3) (Table 3) $54.9 \mathrm{ADH} / 18.3^{\circ} \mathrm{C}=3.00 \mathrm{hrs}$

Determination of oviposition and PMI $\quad$ Backward counting of $3.00 \mathrm{hrs}$ from $30^{\text {th }}$ March 2019 revealed that the female $L$. sericata species might have laid its eggs on the dead body at around 21.00 hrs on $30^{\text {th }}$ March 2019.

Total hours $=\left(2^{\text {nd }}\right.$ April: $17 \mathrm{hrs}+1^{\text {st }}$ April: 24 hrs $+31^{\text {th }}$ March: 24 hrs $+30^{\text {th }}$ March: $\left.3 \mathrm{hrs}\right)=$ $68 \mathrm{hrs}=2.83$ days

Thus the death of the chicken might occur at $21.00 \mathrm{hrs}$ on $30^{\text {th }}$ March 2019 and the calculated PMI after obtaining the third instar larvae was 2.83 days).

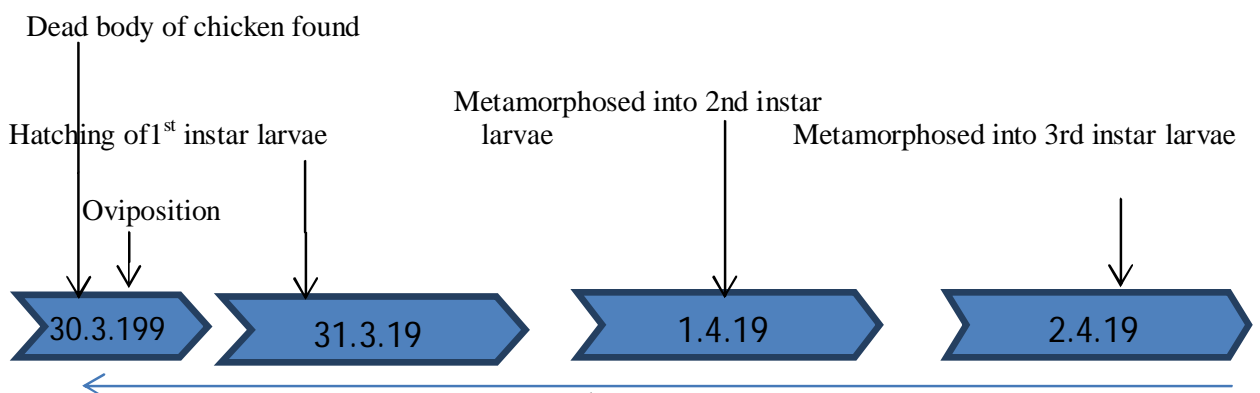

PMI based on $3^{\text {rd }}$ instar larvae of L. sericata

Fig. 2. The timeline indicating the main events in the dead body of the chicken

During the study, it was noticed that the rate of decomposition of chicken was faster than the jungle cat. The investigations were carried out on two fresh dead bodies of a mammalian and an avian model to understand the role the most predominating insect species on the ground. There was difference between the calculated PMIs in case of two animal models. This difference might be due to the variation of temperatures as the larvae 
of the blowfly species developed at $21.3 \pm 1{ }^{\circ} \mathrm{C}$ in the carcass of jungle cat while the larvae of the same species developed at $31 \pm 1^{\circ} \mathrm{C}$ in chicken. The study also revealed that the blowfly, $L$. sericata was found most predominant as well as suitable due to the size and rearing availability of this species. Islam et al., (2016) and Khatun et al., (2018) also reported the presence of blowfly in the carcasses at Jahangirnagar University, Bangladesh. Researchers around the world have used different animals as models for estimations of PMIs. Shean et al., (1993) used pig carcasses, Patrician \& Vaidyanathan (1995) used rats, Tantawi et al., (1996) used rabbit carcasses and Khatun et al., (2019) used only mammalian models-mongoose and mouse in their experiments respectively for the estimation of PMIs.

Although various types of methods are used for estimation of PMI, the present study used $\mathrm{ADH}$ method to estimate post-mortem interval (PMI). Anderson (2000) used the newer concept of accumulated degree days (ADD). Ames and Turner (2003) also applied ADD for estimating post-mortem interval (PMI). The developmental stages of blow fly ( $L$. sericata) larvae were used to calculate post-mortem interval (PMI) in our study because the adult flies were predominant and were found to be the first to reach the carcasses. Similar observations were made by Reed (1958), Tantawi et al., (1996), Bharti \& Singh (2003).

Kulshrestha \& Satpathy (2002) used maggots of Chrysomya rufifacies from three corpses in three cases in the year 2001 from Bhopal, India for the estimation of post-mortem interval (PMI). Ramos-pastrana (2017) estimated the PMI based on the life cycle of Chrysomya albiceps in Colombia and the calculated PMI was of 229 hours (9.5 days). Anderson (1999) described the use of entomology to determine time of death in the illegal killing of two young bear cubs in Manitoba, Canada.

Greenberg \& Wells (1998) used human dead bodies and reported that the phoridae fly may may be only insect evidence, especially in sealed apartments, which are inaccessible to large insects. Bala \& Sharma (2016) calculated the PMI of a 23 years old female corpse found in the rice field of Punjab, India by using ADH method. The PMI of the female was calculated 9.6 days, whereas the autopsy surgeon estimated a PMI to 10 to 12 days. Khatun et al., (2019) carried out an experiment in which the PMIs of two mammalian models - mongoose and mouse were estimated by using ADH method. In their studies they reported that the time of death of mongoose was at around 15.49 hours and the calculated PMI based on the $3^{\text {rd }}$ instar larvae was 3.65 days. In the second case, the estimated PMI based on the $3^{\text {rd }}$ instar larvae was 2.62 days.

However, forensic entomology is not only used to determine the time of death in human death investigations but also it can be equally applicable to wildlife. Since the numbers of poaching are increasing day by day and more animals are killed around the world, the present study can be used in homicide, suspected death and wildlife poaching cases in Bangladesh. 
Conclusion: The $3^{\text {rd }}$ instar larvae of blow fly $L$. sericata collected from the mammalian (F. chaus) and avian (G. g. domesticus) models were used to estimate the post- mortem intervals (PMIs). In the first case study, the obtained results showed that the death of the jungle cat occurred at $3.10 \mathrm{hrs}$ and the calculated PMI based on the third instar larvae was 5.29 days. In the second case study, results revealed that the death of the chicken occurred at $21.00 \mathrm{hrs}$ and the estimated PMI based on the third instar larvae was 2.83 days. There was no significant difference marked between the sequences of faunal succession on both carcasses. The use of forensic entomology in determining the post-mortem interval (PMI) has not been explored properly in our country. Therefore, this study offers necessary tools in the investigations of homicide, suspicious death of animals including wildlife poaching cases in Bangladesh.

Acknowledgement: The research work was carried out in the Laboratory of Medical and Forensic Entomology and at the garden of the Department of Zoology, Jahangirnagar University, Dhaka, Bangladesh. The authors are indebted to the Chairman of the department for extending necessary permissions and facilities to conduct the work.

Declaration: The authors declare that they have equal contributions to this research and have no conflict of interests.

\section{REFERENCES}

Ahmed, A.B. and Joseph, S.G. 2016. Estimation of postmortem interval using the blow fly Phaenicia (Lucilia) sericata (Diptera: Calliphoridae) in Kaduna, Northern Nigeria. Int. J. Res. Med. Sci. 4(8): 3417- 3420.

Ames, C. and Turner, B. 2003. Low temperature episodes in development of blowflies: implications for post-mortem interval estimation. Med. Vet. Entomol. 17(2): 178-86.

Amendt J, Richards C.S, Campobasso C.P, Zehner R, and Hall M.J.R. 2011. Forensic entomology: applications and limitations. Forensic Sci Med Path. doi:10.1007/s12024-010-9209-2.

Anderson, G. S. 1999. Wildlife forensic entomology: determining time of death in two illegally killed black bear cubs. J. Foren. Sci. 44(4): 856-859.

Anderson, G. S. 2000. Minimum and Maximum Development Rates Of Some Forensically Important Calliphoridae (Diptera).J. Foren. Sci. 45(4): 824-832.

Bala, M. and Sharma, A. 2016. Postmortem Interval Estimation of Mummified Body Using Accumulated Degree Hours (ADH) Method.A Case Study from Punjab (India). J. Foren. Sci. \& Criminal Inves. 1(1): 555552.

Benecke, M. 1998. Six forensic entomology cases: description and commentary. J Forensic Sci; 43:797-805.

Bharti, M. and Singh, D. 2003. Insect Faunal Succession on Decaying Rabbit Carcasses in Punjab. J. Foren. Sci. 48: 1133-1143.

Byrd, J. H. and Castner, J. L. 2000. Forensic entomology: The Utility of Arthropods in Legal Investigations. Boca Raton: CRC Press, pp. 440.

Byrd, J. H. and Castner, J. L. 2009. Forensic entomology: The Utility of Arthropods in Legal Investigations. $2^{\text {nd }}$ ed. CRC Press, pp. 681.

Catts, E.P. and Goff, M.L. 1992. Forensic entomology in criminal investigations. Annu.Rev. Entomol. 37:253-272. 
Cervantes, L., Dourel, L., Gaudry, E., Pasquerault, T. and Vincet, B. 2017. Effect of low Temperature in the development cycle of Lucilia sericata (Meigen)(Diptera, Calliphoridae): implications for the minimum postmortem interval Estimation Foren. Sci Res. 3(1): 52-59.

Gennard, D. E. 2007. Forensic Entomology.Wiley, Chichester, UK.PP.224.

Greenberg, B. and Wells, J. D. 1998. Forensic Use of Megaselia abdita and M. scalaris (Phoridae; Diptera): Case Studies, Development Rates and Egg Structure. J. Med. Entomol. 35(3): 205-209.

Islam, M., Hossain, A. Mostafa, M. G., and Hossain, M. M. 2016. Forensically important insects associated with the decomposition of mice carrion in Bangladesh. Jahangirnagar University J. Biol. Sci. 5(1): 2016.

Khatun, R., Mostafa, M. G., Haque, M. E. Ahmad, S. and Akter, T. 2018. Formulation and evaluation of the efficacy of an artificial diet for two forensically important flies. Asian Australas. J. Biosci. Biotechnol. 3(2): 86-92.

Khatun, R., Mostafa, G. and Saadia, A. 2019. Application of forensic entomology to estimate the post-mortem interval (PMI) in mammalian models in Bangladesh. EJBPS. Sci, 6(5): 3845 .

Kulshreshtha, P. and Satpathy, D. K. 2002. Ch. Rufifacies development and forensic entomologyrecent case studies. JIAFM. 24(1): 6-9.

Patrician, L. A. and Vaidyanathan, R. 1995. Arthropod Succession In Rats Euthanized With Carbon Dioxide and Sodium Pentobarbital.J. New York Entomol. Soc. 103(2): 197- 207.

Ramos-Pastrana, Y. and Wolff, M. 2017. Postmortem interval estimation based on Chrysomya albiceps (Diptera, Calliphoridae) in a forensic case in the Andean Amazon, Caqueta, Colombia. Acta Amazonica, 47: 369-74.

Reed, H. B. 1958. A Study of Dog Carcass Communities in Tennessee, With Special Reference to the Insects. Am Midl. Nat. 59(1): 213-245.

Shean, B. S., Messinger, L. and Papworth, M. 1993. Observations of Differential Decomposition on Sun Exposed Vs Shaded Pig Carrion. Coastal Washington State. J. Foren. Sci. 38(4): 938-949.

Suri Babu, B., Sharma, H. and Bharti, M. 2013. Estimation of Postmortem Interval by rearing Chrysomya rufifacies (Macquart, 1842) (Diptera : Calliphoridae): A case study from Central India. J. Foren. Med. Toxicol. 14(2): 1-12.

Tantawi, T. I., ElKady, E. M., Greenberg, B. and ElGhaffar, H. A. 1996. Arthropod Succession on Exposed Rabbit Carrion in Alexandria, Egypt. J. Med. Entomol. 33(4): 566-580.

Williams, K. A. and Villet, M. H. 2014. Morphological identification of Lucilia sericata, Lucilia cuprina and their hybrids (Diptera: Calliphoridae). Zookeys, 420: 69-85.

Youssefi, M. R., Rahimi, M. T. and Marhaba, Z. 2012. Occurrence of Nasal Nosocomial Myiasis by Lucilia sericata (Diptera: Calliphoridae) In North of Iran. Iranian J. Parasitol. 7(1): 104-108. 